\title{
KESADARAN METAKOGNITIF DAN PENGETAHUAN METAKOGNITIF PESERTA DIDIK SEKOLAH MENENGAH ATAS DALAM MEMPERSIAPKAN KETERCAPAIAN STANDAR KELULUSAN PADA KURIKULUM 2013
}

\author{
Yanti Herlanti \\ FITK Universitas IslamNegeri Syarif Hidayatullah \\ email: yantiherlanti@uinjkt.ac.id
}

\begin{abstract}
Abstrak: Penelitian ini bertujuan untuk mendeskripsikan kesadaran metakognitif dan pengetahuan metakognitif peserta didik tingkat Sekolah Menengah Atas. Kesadaran metakognitif merupakan potensi yang dimiliki peserta didik. Pengetahuan metakognitif merupakan kondisi aktual yang ada pada peserta didik. Penelitian bersifat survei ditindaklanjuti dengan eksperimen terbatas. Survei dilakukan di tingkat Sekolah Menengah Atas. SMAN dan MAN di Kota Bogor dan Jakarta menjadi populasi target. Sampel penelitian sebanyak 204 orang peserta didik. Eksperimen terbatas dilakukan pada kelas X SMA Peminatan IPA di SMAN Jakarta Selatan dengan melibatkan 71 peserta didik. Hasil penelitian menunjukkan kesadaran metakognitif (zona potensial) peserta didik rata-rata berada pada kisaran 7583 atau katagori baik, namun pengetahuan metakognitif (zona aktual) berada pada kisaran 10-15 atau katagori sangat buruk. Standar proses yang ditawarkan kurikulum 2013 belum dapat menarik peserta didik pada zona ideal yaitu pengetahuan metakognitif sama dengan kesadaran metakognitif.
\end{abstract}

Kata Kunci: metakognitif, kurikulum 2013, zona aktual, zona potensial, zona ideal

\section{SENIOR HIGH SCHOOL STUDENTS' METACOGNITIVE AWARENESS AND METACOGNITIVE KNOWLEDGE IN ACHIEVING THE GRADUATE STANDARD IN THE 2013 CURRICULUM}

\begin{abstract}
This study was aimed to describe senior high school students' metacognitive awareness and metacognitive knowledge. Metacognitive awareness is the students' potential while metacognitive knowledge is the actual conditions that exist on the students. The study was a survey followed by a limited experiment. The survey was conducted in senior high schools, state senior high schools, and Isamic senior high schools in Bogor and South Jakarta. The sample consisted of 204 students. The limited experiment was carried out in the tenth grade of SMA Peminatan IPA in state senior high schools in South Jakarta involving 71 students. The findings showed that the students 'metacognitive awareness was at the range between 75-83 or in the good category while the students' metacognitive knowledge was at the range between 10-15 or in the very poor category. The process standard offered by the 2013 curriculum has not been able to attract students to the idea level, that is, the metacognitive knowledge and the metacognitive awareness was of equal level.
\end{abstract}

Keywords: metacognitive, 2013 curriculum, actual zone, potential zone, ideal zone

\section{PENDAHULUAN}

Hasil PISA 2009 menunjukkan bahwa hampir semua peserta didik Indonesia untuk mata pelajaran IPA pendidikan dasar (SMP) menguasai pelajaran hanya sampai level 3, sementara Thailand dapat mencapai level 4, dan Singapura level 6. Hasil TIMSS 2007 dan 2011 pada mata pelajaran IPA menunjukkan hampir $95 \%$ peserta didik Indonesia hanya mampu mencapai level menengah. Pencapaian peserta didik di Indonesia lebih rendah dibandingkan negara berkembang di Asia, seperti Malaysia, Thailand, Iran, dan Turki (Kemdikbud, 2013). Hasil studi ini 
menjadi titik tolak pengembangan kurikulum di Indonesia.

Kurikulum 2013 mengembangkan kurikulum sebelumnya, yaitu kurikulum berbasis kompetensi, Kurikulum 2004 dan Kurikulum KTSP tahun 2006 yang mengintegrasikan pengetahuan, keterampilan dan sikap (Kemdikbud, 2013). Ada empat elemen perubahan pada kurikulum 2013, yaitu standar kelulusan, standar isi, standar proses, dan standar penilaian (Kemdikbud, 2013). Berdasarkan standar kompetensi kelulusan, aspek cakupan untuk ranah pengetahuan untuk tingkat sekolah menengah atas meliputi pengetahuan faktual, konseptual, prosedural, dan metakognitif (Kemdikbud, 2013). Standar pengetahuan metakognitif dijadikan standar kelulusan bagi peserta didik SMA dengan harapan mampu meningkatkan kemampuan berpikir peserta didik. Metakognitif menjadi salah satu parameter yang harus dicapai peserta didik tingkat menengah atas pada kurikulum 2013. Parameter metakognitif dianggap penting karena pengetahuan metakognitif menunjang keberhasilan pembelajaran peserta didik. Metakognitif akan mendorong kemampuan peserta didik dalam memecahkan masalah dan pengembangan keterampilan berpikir lebih tinggi (Purnamawati, 2013).

Desmita (2010) mengemukakan bahwa metakognitif atau metakognisi adalah sebuah konstruksi psikologi yang kompleks yang meliputi pengetahuan dan kesadaran tentang proses kognisi atau pengetahuan tentang pikiran dan cara kerjanya. Berdasarkan definisi ini, metakognitif terbagi menjadi dua, yaitu kesadaran metakognitif dan pengetahuan metakognitif. Kesadaran metakognitif berkembang dari hanya sekedar pengetahuan (knowledge) dan pengaturan pengetahuan (regulation of cognition) menjadi strategi dan keterampilan yang mendorong peserta didik memecahkan permasalahan dan berpikir tingkat tinggi (Schraw \& Dennison, 1994). Berdasarkan perkembangan kesadaran metakognitif didefinisikan kemampuan dalam melakukan refleksi, memahami, dan mengontrol pembelajaran. Adapun pengetahuan metakognitif (Rampoyam, et al., 2010) terdiri atas pengetahuan untuk mencari informasi/sumber informasi yang dibutuhkan sebagai usaha dari tugas yang diberikan (pengetahuan deklaratif), pengetahuan mengenai pendapat pribadi terhadap tugas yang diberikan (pengetahuan prosedural), dan pengetahuan mengenai kapan serta mengapa menggunakan strategi tersebut untuk memecahkan suatu masalah (pengetahuan kondisional).

Instrumen kesadaran metakognitif pertama kali dikembangkan oleh Schraw \& Dennison (1994) dengan nama MAI (A Metacognitive Awareness Inventory). Instrumen ini digunakan lebih lanjut oleh para peneliti untuk berbagai kepentingan, seperti oleh Gassner \& Warfvinge (2009), Young \& Fry (2009), Balcikanli (2011) dan Yildirim \& Ersözlü (2013). Bahkan, Sperling et.al (2002) dari instrumen MAI dikembangkan menjadi instrumen Jr MAI (Junior Metacognitive Awerness Inventory) untuk peserta didik di pendidikan dasar terutama kelas 3-8.

Adapun instrumen pengetahuan metakognitif dikembangkan sesuai dengan mata pelajaran. Rompayam, et. al. (2010) mengembangan instrumen pengetahuan metakognitf untuk mata pelajaran kimia sekolah menengah. Instrumen dikembangkan untuk menggali pengetahuan deklaratif, prosedural, dan kondisional.

Standar kelulusan dengan parameter pencapaian pengetahuan metakognitif dapat dicapai apabila ditunjang proses pembelajaran yang dilakukan guru di kelas. Berdasarkan Peraturan Kementerian Pendidikan dan Kebudayaan (2013), standar proses pembelajaran yang dapat dilakukan guru di kelas terbagi menjadi dua, yaitu pendekatan utama dan pendukung. Pendekatan utama meliputi pendekatan ilmiah (scientific), tematik terpadu (tematik antarmata pelajaran), dan tematik (dalam suatu mata pelajaran). Pendekatan pendukung meliputi pembelajaran berbasis penyingkapan/penelitian (discovery/inquiry learning) dan pendekatan pembelajaran yang menghasilkan karya berbasis pemecahan masalah (project based learning). Pendekatan sainstifik merupakan pendekatan pembelajaran yang paling utama digunakan dalam proses pembelajaran semua mata pelajaran, termasuk biologi. Pendekatan ini terejawantahkan dalam pembuatan perencanaan pembelajaran dan pelaksanaan pembelajaran di kelas. 
Bagaimana potensi kemampuan metakognitif peserta didik? Bagaimana tingkat pengetahuan yang telah dicapai peserta didik? Apakah proses pembelajaran sesuai standar proses kurikulum 2013, yaitu menggunakan pendekatan saintifik dan pembelajaran berbasis masalah mampu meningkatkan pengetahuan metakognitif peserta didik? Penelitian ini bertujuan untuk menjawab pertanyaan-pertanyaan tersebut, sehingga diperoleh gambaran secara empirik kesadaran metakognitif dan pengetahuan metakognitif yang dimiliki oleh peserta didik. Gambaran empirik juga menjadi bahan evaluasi terhadap proses pembelajaran yang telah dilakukan dan memberikan solusi apa yang harus diperbaiki pada proses pembelajaran sehingga pengetahuan metakognitif dapat diraih peserta didik Indonesia.

\section{METODE}

Penelitian ini menggunakan pendekatan kuantitattif dengan strategi berurutan/sequencial (Creswell, 2014). Metode penelitian yang digunakan adalah survei ditindaklanjuti dengan eksperimen kuasi. Desain penelitian secara bertahap dapat dilihat pada Tabel 1 .

Survei dilakukan pada 204 peserta didik Kelas XI Kota Bogor dan Jakarta Selatan yang terpilih melalui pemilihan stratafikasi (perjenjangan). Kota Bogor dan Kota Jakarta Selatan mempunyai karakteristik yang berbeda SMAN/ MAN Kota Bogor dibagi menjadi empat level berdasarkan nilai UN SMA. Level I yang memiliki nilai UN lebih dari 36 (skala 1-10, dengan 4 mata pelajaran), level II yang memiliki nilai UN 35-36, level III memiliki nilai UN 3234, dan level IV dengan nilai UN 28-32. Di Kota Jakarta Selatan, mekanisme penerimaan murid baru berdasarkan lokasi terdekat. Setiap sekolah berpotensi memiliki kualitas yang sama. Berdasarkan karakteristik populasi target seperti ini, sampel di Kota Bogor dipilih secara acak satu sekolah yang mewakili level I-IV, dan untuk sampel di Kota Jakarta Selatan dipilih satu sekolah MAN dan satu sekolah SMAN. Peserta didik kelas XI tahun 2014 di SMAN Kota Bogor dan Jakarta Selatan telah menerapkan Kurikulum 2013, adapun peserta didik kelas XI di MAN Kota Bogor dan Jakarta Selatan belum menerapkan Kurikulum 2013.

Eksperimen penerapan strategi pembelajaran Kurikulum 2013 (Pendekatan sainstifik dan pembelajaran berbasis masalah) dilakukan di kelas X SMAN Jakarta Selatan. Sampel dipilih secara acak pada kelompok kelas Peminatan Ilmu Pengetahuan Alam (MIA). Sampel yang terpilih adalah kelas MIA 1 berjumlah 35 orang peserta didik (menerapkan pendekatan sainstifik) dan Kelas MIA 2 berjumlah 36 orang peserta didik (menerapkan pembelajaran berbasis masalah).

Penelitian ini menggunakan instrumen tes berupa Metacognitive Awareness Inventory (MAI) yang diadaptasi dari Schraw and Dennison (1994). Instrumen ini mengalami proses adaptasi menyesuaikan dengan konteks Indonesia (Sperber, 2011). Instrumen MAI yang telah diadaptasi divalidasi oleh seorang ahli psikologi kognitif dari Universty of Malaya. Instrumen yang sudah divalidasi ahli selanjutnya diuji keterbacaan dan pengukuran reliabilatas. Proses uji keterbacaan dan pengukuran reliabilitas soal di lapangan melibatkan 40 orang peserta didik berumur 15-16 tahun di sebuah SMAN Bogor. Hasil validasi lapang dengan menggunakan alfa cronbach dengan bantuan program SPPSS menunjukkan 45 soal valid yang digunakan dalam penelitian dan didapatkan nilai alpha sebesar 0.879 yang artinya item angket reliabel atau terpercaya sebagai alat pengumpul data (Indeks 1.)

Tabel 1. Metode Penelitian yang Digunakan

\begin{tabular}{|c|c|c|}
\hline Metode & Desain & Tujuan \\
\hline Survei & - & $\begin{array}{l}\text { Menggali kesadaran dan pengetahuan metakognitif peserta } \\
\text { didik SMA }\end{array}$ \\
\hline Eksperimen & $\begin{array}{l}\text { Non-equavalent Pre Test and } \\
\text { Post test Control Group Design } \\
\text { Kelompok A: } 0 \text {--- X --- } 0 \\
\text { Kelompok B: } 0 \text {--- X --- }\end{array}$ & $\begin{array}{l}\text { Mengetahui pencapaian dan peningkatan pengetahuan } \\
\text { metakognitif melalui penerapan beragam pendekatan } \\
\text { pembelajaran pada kurikulum } 2013\end{array}$ \\
\hline
\end{tabular}


Keterangan:

Kelompok A (Peserta didik yang belajar menggunakan pendekatan sainstifik)

Kelompok B (Peserta didik yang belajar menggunakan Pembelajaran Berbasis Masalah/Problem Based Learning)

Intrumen pengetahuan metakognitif dikembangkan dari instrumen Rompayom et al (2010). Jika Rompayom mengembangkan instrumen untuk mata pelajaran kimia SMA, maka penelitian ini dikembangkan untuk mata pelajaran sains, yaitu terkait konsep virus dan pencemaran udara pada matapelajaran biologi kelas $\mathrm{X}$. Instrumen pengetahuan yang telah dibuat sesuai parameter pengetahuan metakognitif diverifikasi oleh dua pakar pendidikan alumnus Universitas Pendidikan Indonesia. Uji keterbacaan instrumen diberikan pada 10 orang siswa, mereka diminta memberi komentar "apakah memahami soal yang diberikan atau tidak". Instrumen pengetahuan metakognitif lengkap dan rubrik penilaianya dapat dilihat pada indeks 2 dan 3.

Data kuanitatif dilakukan analisis statistik inferensi menggunakan program SPSS Version 21. Statistik inferensi yang digunakan adalah adalah Analisis Ovarian (ANOVA) dilanjutkan dengan uji lanjutan Turkey untuk melihat perbedaan kesadaran dan pengetahuan metakognitif antarsekolah.

Analisis hasil jawaban pengetahuan metakognitif dilakukan secara deskriptif. Tidak semua jawaban respoden dianalisis secara deskriptif, dari 173 jawaban dipilih 4 jawaban peserta didik mewakili perolahan kesadaran meta- kognitif terendah dan tertinggi.

Analisis data peningkatan pengetahuan metakognitif disebabkan oleh strategi pembelajaran pada kurikulum 2013 dilakukan dengan menggunakan normal gain (N-gain). Rumus Ngain adalah sebagai berikut (Hake, 1999).

$$
\begin{aligned}
& N-\text { gain }(g) \\
& \text { Nilai posttest }(\%)-\text { nilai } \operatorname{pretest}(\%) \\
& \begin{array}{c}
100-\text { nilai pretest }(\%) \\
\text { Keterangan: }
\end{array}
\end{aligned}
$$

\section{Keterangan:}

Tinggi $\mathrm{g}>0,7$

Sedang $0,3>\mathrm{g}>0,7$

Rendah $g<0,3$

\section{HASIL DAN PEMBAHASAN}

\section{Kesadaran Metakognitif}

Tabel 2 memperlihatkan perolehan kesadaran metakognitif peserta didik berdasarkan perbedaan sekolah dan jenis sekolah yang menerapkan kurikulum 2013. Tabel 1 memperlihatkan perbedaan kesadaran metakognitif antar sekolah tidak terlalu mencolok kecuali pada MA A tidak didasarkan pada perbedaan wilayah atau pun tidak berdasarkan perbedaan jenis dan level sekolah, tetapi lebih bersifat individual peserta didik. Perbedaan yang mencolok terlihat pada MA A yang terletak di Jakarta Selatan, hasil uji statistik menunjukkan perbedaan yang signifikan rerata kesadaran metakognitif antar sekolah. Perbedaan rerata antara sekolah yang telah menerapkan dan belum menerapkan Kurikulum 2013 juga tidak begitu besar, dan hasil uji statistik juga menunjukkan tidak ada perbedaan yang signifikan.

Tabel 2. Perolehan Kesadaran Metakognitif Peserta Didik Berdasarkan Sekolah

\begin{tabular}{llllc}
\hline \multicolumn{1}{c}{ Sekolah } & & Per Sekolah & \multicolumn{2}{c}{$\begin{array}{c}\text { Per Jenis Sekolah (sesuai dengan } \\
\text { Penerapan Kurikulum 2013 }\end{array}$} \\
\cline { 2 - 5 } & Rerata (\%) & Rerata jumlah ranking & Rerata (\%) & Standar deviasi \\
\hline SMA A & 78,89 & 101,24 & & \\
SMA B & 79,40 & 104,91 & 79,09 & 7,35 \\
SMA C & 79,16 & 103,78 & & \\
SMA D & 82,68 & 130,54 & & 8,56 \\
MA A & 74,70 & 70,20 & 78,59 & \\
MA B & 81,62 & 121,96 & F $=2.31$ & \\
Hasil Uji Beda rerata & F=4.20 & & Sig. 0.13 & \\
& Sig. 0.01 & & &
\end{tabular}


Tabel 3. Hasil Uji Lanjutan Turkey terhadap Perbedaan Rerata Kesadaran Metakognitif Berdasarkan Jenis Sekolah

\begin{tabular}{|c|c|c|c|c|c|c|}
\hline $\begin{array}{c}\text { Kode } \\
\text { Sekolah } \\
\end{array}$ & SMA A & SMA B & SMA C & SMA D & MA A & MA B \\
\hline SMA A & - & $\begin{array}{l}\text { Tidak } \\
\text { terdapat } \\
\text { perbedaan } \\
\text { (Sig 1.00) }\end{array}$ & $\begin{array}{l}\text { Tidak } \\
\text { terdapat } \\
\text { perbedaan } \\
\text { (Sig 1.00) }\end{array}$ & $\begin{array}{l}\text { Tidak } \\
\text { terdapat } \\
\text { perbedaan } \\
\text { (Sig } 0.27 \text { ) }\end{array}$ & $\begin{array}{l}\text { Tidak } \\
\text { terdapat } \\
\text { perbedaan } \\
\text { (Sig 0.26) }\end{array}$ & $\begin{array}{l}\text { Tidak terdapat } \\
\text { perbedaan (Sig } \\
0.63 \text { ) }\end{array}$ \\
\hline SMA B & 1.00 & - & $\begin{array}{l}\text { Tidak } \\
\text { terdapat } \\
\text { perbedaan } \\
\text { (Sig (1.00) }\end{array}$ & $\begin{array}{l}\text { Tidak } \\
\text { terdapat } \\
\text { perbedaan } \\
\text { (Sig 0.46) }\end{array}$ & $\begin{array}{l}\text { Tidak } \\
\text { terdapat } \\
\text { perbedaan } \\
\text { (Sig 0.18) }\end{array}$ & $\begin{array}{l}\text { Tidak terdapat } \\
\text { perbedaan (Sig } \\
0.82 \text { ) }\end{array}$ \\
\hline SMA C & 1.00 & 1.00 & - & $\begin{array}{l}\text { Tidak } \\
\text { terdapat } \\
\text { perbedaan } \\
\text { (Sig 0.43) }\end{array}$ & $\begin{array}{l}\text { Tidak } \\
\text { terdapat } \\
\text { perbedaan } \\
\text { (Sig 0.22) }\end{array}$ & $\begin{array}{l}\text { Tidak terdapat } \\
\text { perbedaan (Sig } \\
0.79 \text { ) }\end{array}$ \\
\hline SMA D & 0.27 & 0.46 & 0.43 & - & $\begin{array}{l}\text { Terdapat } \\
\text { perbedaan } \\
\text { (Sig 0.01) }\end{array}$ & $\begin{array}{l}\text { Tidak terdapat } \\
\text { perbedaan (Sig } \\
0.99 \text { ) }\end{array}$ \\
\hline MA A & 0.26 & 0.18 & 0.22 & 0.01 & - & $\begin{array}{l}\text { Terdapat } \\
\text { perbedaan (Sig } \\
0.05 \text { ) }\end{array}$ \\
\hline MA B & 0.63 & 0.82 & 0.79 & 0.99 & 0.05 & - \\
\hline
\end{tabular}

Tabel 4. Komponen Kesadaran Metakognitif yang Paling Rendah Berdasarkan Persepsi Peserta Didik SMA/MA di Bogor dan Jakarta Selatan

\begin{tabular}{|c|c|c|c|}
\hline No. & Komponen & Pertanyaan pada Peserta Didik & Rerata Skor \\
\hline \multirow[t]{3}{*}{1.} & $\begin{array}{l}\text { Kegiatan refleksi } \\
\text { terhadap penguasaan }\end{array}$ & $\begin{array}{l}\text { 34. Saya menggunakan gambar atau diagram selama pembela- } \\
\text { jaran untuk membantu memahami materi. }\end{array}$ & 2.52 \\
\hline & materi & $\begin{array}{l}\text { 37. Saya menggunakan peta konsep untuk membantu saya } \\
\text { belajar }\end{array}$ & 2.54 \\
\hline & & $\begin{array}{l}\text { 21. Saya membuat ringkasan atas materi yang telah saya pelajari } \\
\text { setelah selesai pembelajaran }\end{array}$ & 2.76 \\
\hline \multirow[t]{3}{*}{2.} & $\begin{array}{l}\text { Kegiatan refleksi } \\
\text { terhadap kemampuan }\end{array}$ & $\begin{array}{l}\text { 19. Saya bertanya pada diri saya sendiri tentang materi pe- } \\
\text { lajaran sebelum pelajaran dimulai }\end{array}$ & 2.72 \\
\hline & diri & $\begin{array}{l}\text { 20. Saya secara berkala menilai diri untuk membantu saya } \\
\text { memahami kaitan-kaitan penting }\end{array}$ & 2.98 \\
\hline & & $\begin{array}{l}\text { 31. Saya menemukan sendiri waktu jeda untuk mengecek ke- } \\
\text { mampuan secara teratur }\end{array}$ & 2.77 \\
\hline \multirow[t]{2}{*}{3.} & $\begin{array}{l}\text { Kegiatan ekplorasi } \\
\text { dan elaborasi }\end{array}$ & $\begin{array}{l}\text { 28. Saya membuat sendiri beberapa contoh untuk membuat } \\
\text { informasi lebih bermakna (elaborasi) }\end{array}$ & 2.78 \\
\hline & $\begin{array}{l}\text { terhadap penguasaan } \\
\text { materi }\end{array}$ & $\begin{array}{l}\text { 30. Saya menemukan sendiri penggunaan strategi pembelajaran } \\
\text { yang paling bermanfaat secara ototmatis (ekplorasi) }\end{array}$ & 2.93 \\
\hline
\end{tabular}

Tabel 3 menunjukkan hasil uji lanjutan untuk perbedaan rerata antar jenis sekolah yang perbedaannya signifikan. Tabel 3 menunjukkan perbedaan signifikan terjadi pada MA A di Jakarta Selatan dan SMA D di Jakarta Selatan serta MA B di Bogor. MA di Jakarta Selatan mempunyai kebijakan kurikulum yang berbeda dengan SMA dan MA di Bogor. MA A di Jakarta Selatan menerapkan pembelajaran bersifat Sistem Kredit Semester (SKS). Pembelajaran 
dilakukan dengan sistem modul dan akseleratif. Sifat kurikulum SKS membuat peserta didik merasa kehilangan waktu untuk melakukan kegiatan yang menumbuhkan kesadaran metakognitif.

Tabel 4 menunjukkan komponen kesadaran metakognitif yang perolehannya paling rendah. Pada Tabel 4 terlihat bahwa peserta didikjarang melakukan kegiatan ekplorasi, refleksi, dan elaborasi untuk lebih menguasai materi pembelajaran. Peserta didik pun jarang melakukan kegiatan refleksi untuk mengukur kemampuan dirinya.

\section{Pengetahuan Metakognitif}

\section{Analisis Kuantitas Pengetahuan Metakognitif}

Kemampuan peserta didik dalam mencapai kompetensi pengetahuan metakognitif sangat rendah. Rerata yang didapatkan masingmasing sekolah kurang dari 20\% (nilai maksimal 100\%). Tabel 5 memperlihatkan MA B menunjukkan perolehan paling rendah dibandingkan sekolah lain, dan perbedaan rerata secara signifikan terjadi antar sekolah. Adapun antar sekolah yang telah menerapkan kurikulum 2013 dan belum menerapkan Kurikulum 2013 tidak terjadi perbedaan yang signifikan.

Tabel 6 memperlihatkan perbedaan signifikan antarsekolah terjadi pada MA B. Rerata pengetahuan metakognitif MA B berbeda signifikan dengan sekolah menengah atas yang ber- ada di Kota Bogor dan Jakarta Selatan. MA B merupakan sekolah dengan masukan (input) kemampuan peserta didik paling rendah (Level IV = nilai UN SMP 28-32). Adapun antar sekolah dengan masukan peserta didik pada level I (SMA C), level II (SMA B), dan level III (SMA A), pengetahuan metakognitif peserta didik tidak menunjukkan perbedaan yang signifikan. Tabel 5 juga dapat menunjukkan posisi MA di Jakarta Selatan, yang setara dengan SMA level II dan III di (nilai UN SMP kisaran 32-36), namun berbeda signifikan dengan sekolah menengah level I (nilai UN SMP lebih besar dari 36).

\section{Tabel 5. Pengetahuan Metakognitif Peserta} Didik

\begin{tabular}{|c|c|c|c|c|}
\hline \multirow[t]{2}{*}{ Sekolah } & \multicolumn{2}{|c|}{ Per Sekolah } & \multicolumn{2}{|c|}{$\begin{array}{c}\text { Per jenis Sekolah } \\
\text { (sesuai Penerapan } \\
\text { Kurikulum } 2013\end{array}$} \\
\hline & $\begin{array}{c}\text { Rerata } \\
(\%)\end{array}$ & $\begin{array}{l}\text { Standar } \\
\text { Deviasi }\end{array}$ & $\begin{array}{c}\text { Rerata } \\
(\%) \\
\end{array}$ & $\begin{array}{l}\text { Standar } \\
\text { Deviasi }\end{array}$ \\
\hline SMA A & 14.54 & 7,17 & & \\
\hline SMA B & 14.91 & 8,00 & 15,42 & 7,13 \\
\hline SMA C & 17.17 & 5,95 & & \\
\hline MA A & 12.53 & 7,70 & 10,89 & 6,57 \\
\hline MA B & 9.78 & 5,48 & \multirow{2}{*}{\multicolumn{2}{|c|}{$F=0.147$}} \\
\hline Hasil & \multirow{2}{*}{\multicolumn{2}{|c|}{$F=7.162$}} & & \\
\hline Uji & & & Sig. 0.701 & \\
\hline $\begin{array}{l}\text { Beda } \\
\text { rerata }\end{array}$ & \multicolumn{2}{|c|}{ Sig. 0.000} & & \\
\hline
\end{tabular}

Tabel 6. Hasil Uji Lanjutan Turkey terhadap Perbedaan Rerata Pengetahuan Metakognitif Berdasarkan Jenis Sekolah

\begin{tabular}{|c|c|c|c|c|c|}
\hline $\begin{array}{c}\text { Kode } \\
\text { Sekolah }\end{array}$ & $\begin{array}{c}\text { SMA A } \\
\text { (3) }\end{array}$ & $\begin{array}{c}\text { SMA B } \\
\text { (4) }\end{array}$ & $\begin{array}{c}\text { SMA C } \\
(5)\end{array}$ & $\begin{array}{c}\text { MA A } \\
\text { (1) }\end{array}$ & $\begin{array}{c}\text { MA B } \\
(2)\end{array}$ \\
\hline $\begin{array}{l}\text { SMA A } \\
\text { (3) }\end{array}$ & - & $\begin{array}{l}\text { Tidak terdapat } \\
\text { perbedaan } \\
\text { (Sig 0.999) }\end{array}$ & $\begin{array}{l}\text { Tidak terdapat } \\
\text { perbedaan } \\
(\text { Sig 0.541) }\end{array}$ & $\begin{array}{l}\text { Tidak terdapat } \\
\text { perbedaan } \\
(\text { Sig 0.703) }\end{array}$ & $\begin{array}{l}\text { Terdapat perbedaan } \\
\quad \text { (Sig 0.09) }\end{array}$ \\
\hline SMA B (4) & 0.999 & - & $\begin{array}{l}\text { Tidak terdapat } \\
\text { perbedaan } \\
(\operatorname{Sig}(0.689)\end{array}$ & $\begin{array}{c}\text { Tidak terdapat } \\
\text { perbedaan } \\
\text { (Sig 0.550) }\end{array}$ & $\begin{array}{c}\text { Terdapat perbedaan } \\
\text { (Sig 0.04) }\end{array}$ \\
\hline SMA C (5) & 0.541 & 0,689 & (5) & $\begin{array}{c}\text { Terdapat perbedaan } \\
\quad(\text { Sig } 0.048)\end{array}$ & $\begin{array}{c}\text { Terdapat perbedaan } \\
\quad(\text { Sig } 0.00)\end{array}$ \\
\hline $\begin{array}{c}\text { MA A } \\
\text { (1) }\end{array}$ & 0.703 & 0.550 & 0.048 & 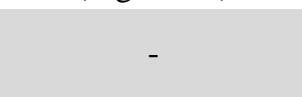 & $\begin{array}{c}\text { Tidak terdapat } \\
\text { perbedaan (Sig 0.309) }\end{array}$ \\
\hline MA B (2) & 0.09 & 0.04 & 0.00 & 0.309 & - \\
\hline
\end{tabular}




\section{Analisis Hasil Jawaban Soal Pengetahuan Metakognitif}

Analisis pengetahuan metakognitif peserta didik yang mempunyai kesadaran metakognitif rendah menunjukkan kegagalan mengemukan pengetahuan metakognitif deklaratif yang diperlukan untuk menjawab soal (nomor dua). Gambar 2a menunjukkan peserta didik tidak memberikan pengetahuan yang diperlukan, tetapi memberikan alasan untuk jawabannya. Gambar $2 \mathrm{~b}$ menunjukkan peserta didik gagal dalam merinci pengetahuan yang diperlukan untuk menjawab pertanyaan yang ada.

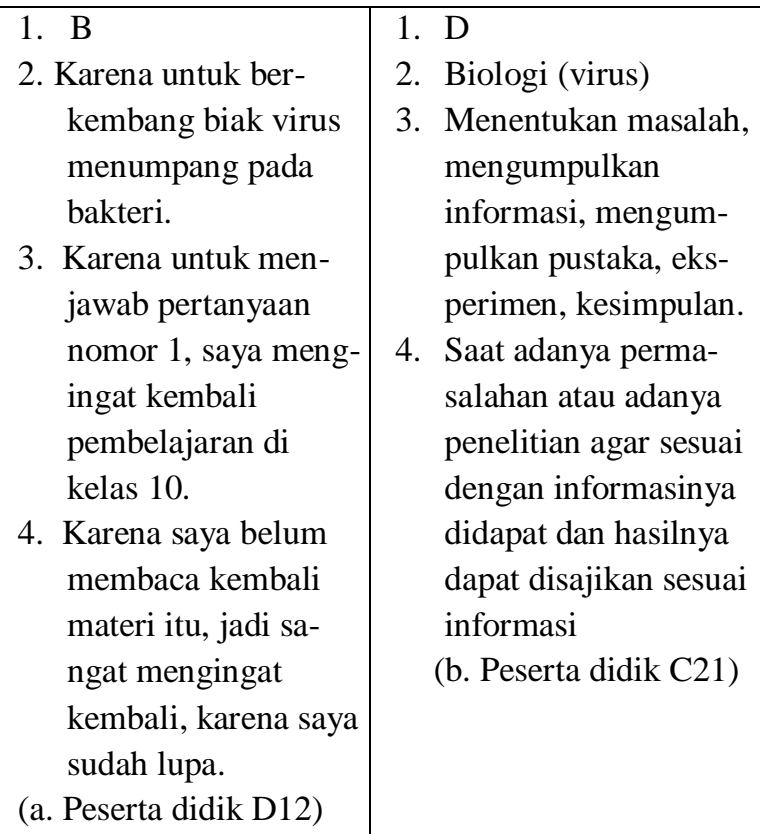

Gambar 1. Jawaban Peserta Didik D.12 dan C.21

Peserta didik gagal dalam mengemukakan pengetahuan metakognitif prosedural (jawaban nomor tiga), yaitu bagaimana tahapan langkah yang dilakukan dalam memperoleh jawaban yang yang dikemukakan. Gambar 2a memperlihatkan tahapan langkah yang terlalu umum tidak menunjukkan langkah untuk menjawab pertanyaan yang spesifik terkait "apakah virus layak dikatagorikan sebagai makhluk hidup". Gambar 2b memperlihatkan rincian langkah yang dilakukan, tetapi langkah yang dikemukan tersebut merupakan langkah metode ilmiah yang tidak relevan dengan proses kognitif yang dilakukan untuk menjawab pertanyaan yang ada.

Peserta didik juga gagal dalam mengemukakan pengetahuan metakognitif kondisional (jawaban nomor empat). Gambar 1a menunjukkan peserta tidak menjawab pertanyaan, tetapi memberikan alasan mengapa dia tidak bisa menjawab pertanyaan tersebut. Gambar 1b menunjukkan peserta didik menjawab untuk kondisi diluar dari konteks yang ditanyakan.

\begin{tabular}{|c|c|}
\hline $\begin{array}{l}\text { 1. Saya setuju karena } \\
\text { kalau tidak ada at- } \\
\text { mosfer, matahari } \\
\text { akan memancarkan } \\
\text { langsung cahayanya } \\
\text { tanpa di serap apa- } \\
\text { pun. Hal itu akan } \\
\text { meyebabkan bumu } \\
\text { sangat panas sekali. } \\
\text { 2. Pengetahuan ilmu- } \\
\text { ilmu kimia dan ilmu } \\
\text { astronomi. } \\
\text { 3. Membaca dengan } \\
\text { teliti, memahami, } \\
\text { menjawab. } \\
\text { 4. Sejak kecil karena } \\
\text { segala sesuatu harus } \\
\text { dilakukan secara } \\
\text { teliti. } \\
\text { (a. Peserta didik } \\
\text { C21) }\end{array}$ & $\begin{array}{l}\text { 1. Menurut saya tepat, } \\
\text { grafik suhu yang } \\
\text { terus meningkat } \\
\text { dari tahun ketahun } \\
\text { dikarenakan emini } \\
\text { karbon, sudah } \\
\text { kehendak yang } \\
\text { maha kuasa. } \\
\text { 2. Geografi, biologi, } \\
\text { ilmu kebumian. } \\
\text { 3. Belajar: membaca } \\
\text { materi, menentukan } \\
\text { strategi, merang- } \\
\text { kum, memahami. } \\
\text { 4. Kapan saja sesuai } \\
\text { kebutuhan, karena } \\
\text { itu adalah cara } \\
\text { belajar saya. } \\
\text { (b. Peserta didik E37) }\end{array}$ \\
\hline
\end{tabular}

\section{Gambar 2. Jawaban Peserta Didik C21 dan} E.37

Analisis kualitas pengetahuan metakognitif peserta didik dengan kesadaran metakognitif tinggi menunjukkan peserta didik yang mempunyai kesadaran metakognitif tinggi, juga menunjukkan hal yang sama. Peserta didik dengan kesadaran metakognitif tinggi mengalami kegagalan dalam mengindentifikasi pengetahuan yang diperlukan untuk menjawab pertanyaan nomor 2 (pengetahauan deklaratif), 3 (pengetahuan prosedural), dan 4 (pengetahuan kondisional). Peserta didik hanya memaparkan hal umum bukan hal spesifik yang tertera dalam wacana 
dalam menjawab pertanyaan nomor 2 (Gambar $2 \mathrm{a}$ dan $2 \mathrm{~b}$ ). Jawaban untuk pengetahuan metakognitif prosedural (nomor 3), peserta didik sudah menunjukkan langkah yang dilakukan untuk menjawab pertanyaan, hanya saja langkah tersebut masih terlalu umum tidak tidak lengkap dan tidak sesuai konteks pertanyaan (Gambar $2 \mathrm{a}$ dan $2 \mathrm{~b}$ ). Pertanyaan terkait pengetahuan metakognitif kondisional (jawaban nomor 4) gagal dipahami oleh perserta didik dengan kesadaran metakognitif tinggi, jawaban yang diberikan di luar dari konteks yang ditanyakan.

\section{Penerapan Standar Proses pada Kurikulum 2013 terhadap Perolehan Pengetahuan Meta- kognitif Peserta Didik}

Perolehan pengetahuan metakognitif yang rendah diduga karena proses pembelajaran yang digunakan oleh pengajardi kelas. Pengajardi kelas belum sepenuhnya memahami standar proses pembelajaran untuk mencapai kompetensi pengetahuan metakognitif. Standar proses Kurikulum 2013 memberikan tiga pendekatan utama dan tiga pendekatan pendukung sebagai sarana untuk mencapai standar kompetensi lulusan, termasuk kompetensi dalam memperoleh pengetahuan metakognitf. Penelitian ini mengimplementasikan satu pendekatan utama, yaitu pendekatan saintifik dan satu pendekatan pendukung, yaitu pembelajaran berbasis masalah. Pada penelitian ini, guru melakukan pengajaran sesuai dengan sintaks pendekatan saintifik dan pembelajaran berbasis masalah. Topik pengajaran yang digunakan adalah virus. Hasil perolehan pengetahuan metakognitif untuk soal yang sama dengan soal survei (indeks 2) terlihat pada Tabel 7.
Pada Tabel 7 terlihat bahwa standar proses sesuai kurikulum 2013 telah diterapkan, namun perolehan pengetahuan metakognitif peserta didik masih rendah. Hasil ini tidak jauh berbeda dengan hasil survei yang telah dilakukan.

Berdasarkan rerata $\mathrm{N}$-gain, peserta didik yang menggunakan pendekatan berbasis masalah menunjukkan peningkatan pengetahuan metakognitif lebih tinggi daripada pendekatan saintifik. Namun, katagori peningkatan pengetahuan metakognitif sangat rendah. Peningkatan pengetahuan metakognitif setelah melakukan pembelajaran sesuai dengan standaar proses Kurikulum 2013 masih kurang dari $10 \%$.

\section{Pembahasan}

Kesadaran metakognitif peserta didik sudah cukup baik, namun perolehan pengetahuan metakognitif peserta didik sangat rendah. Kesadaran metakognitif lebih bersifat persepsi peserta didik terhadap apa yang biasa mereka lakukan atau potensi yang dimiliki perserta didik, sedangkan pengetahuan menunjukkan kemampuan nyata yang ditunjukkan peserta didik. Jika dikaitkan dengan teori Zona Proximal Development Vygotsky (Moll, 1990), hubungan antara kesadaran metakognitif dan pengetahuan metakognitif terlihat pada Gambar 3.

Pada Gambar 3 terlihat bahwa harus ada upaya berupa pembelajaran dan pemberian tuntunan sehingga peserta didik dapat mencapai zona ideal berdasarkan zona potensial dan aktual. Hal yang harus dicapai adalah bagaimana pembelajaran dan tuntunan dapat menghantarkan peserta didik dalam meraih pengetahuan metakognitif yang lebih tinggi karena secara aktual pengetahuan metakognitif sangat rendah.

Tabel 7. Hasil Pengetahuan Metakognitif Menggunakan Proses Pembelajaran sesuai Panduan Kurikulum 2013

\begin{tabular}{lllll}
\hline Hasil & \multicolumn{2}{l}{ Pendekatan Sainstifik } & \multicolumn{2}{l}{ Pembelajaran Berbasis Masalah } \\
\cline { 2 - 5 } & Pre tes & Pos tes & Pre tes & Pos tes \\
\hline Rerata & 27,99 & 30,74 & 44.57 & 52,88 \\
Standar deviasi & 13,82 & 14,80 & 14,85 & 12,41 \\
Rerata n-Gain & 0.04 & & 0.15 & \\
& Rendah & & Rendah & \\
\hline
\end{tabular}




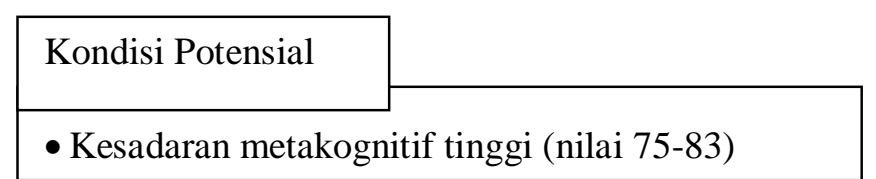

Kondisi Aktual

- Pengetahuan metakognitif rendah (nilai 10-15)

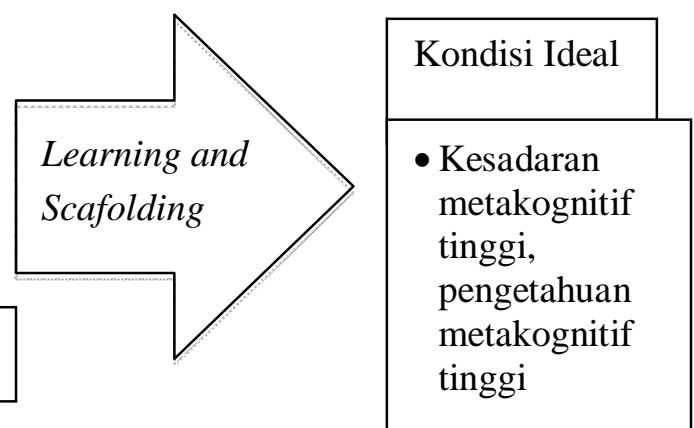

\section{Gambar 3. Hubungan antara Kondisi}

\section{Potensial, Aktual, dan Ideal}

Kementrian Pendidikan dan Kebudayaan Republik Indonesia (2013) telah menggagas standar proses pembelajaran di kelas, yaitu pendekatan saintifik, inkuiri/diskoveri, pembelajaran berbasis masalah dan proyek. Harapannya, pendekatan-pendekatan ini dapat menarik kondisi aktual peserta didik menuju kondisi ideal sesuai dengan kondisi potensialnya.

Hasil riset eksperimen untuk pendekatan saintifik dan pembelajaran berbasis masalah menunjukkan pengetahuan metakognitif yang diperoleh peserta didik sangat rendah. Pendekatan pembelajaran yang disarankan pada Kurikulum 2013, yaitu pendekatan saintifik dan pembelajaran berbasis masalah belum dapat menghantarkan peserta didik untuk mencapai kondisi ideal sesuai potensinya. Hasil belajar untuk pengetahuan metakognitif nilainya rendah, dan peningkatannya pun rendah. Purnawati (2010) menyatakan bahwa praktik pembelajaran yang mendorong peserta didik untuk bertanya, mencari solusi masalah nyata, dan menampilkan hasil kerjanya dapat mengembangkan metakognisi dan melatih siswa menjadi pembelajar mandiri (self regulated learner). Hasil penelitian masih menunjukkan pendekatan sainstifik yang mendorong peserta didik untuk bertanya dan pembelajaran masalah yang mendorong untuk mencari solusi masalah nyata belum dapat meningkatkan pengetahuan metakognitif.

Beberapa hal yang menyebabkan pembelajaran sainstifik dan pembelajaran berbasis masalah belum dapat meningkatkan pengetahuan metakognitif adalah kedua pendekatan itu belum mampu melatih pembelajar mengatur diri (self regulated learner/SLR). Whitebread \& Car- denas (2012) mengemukakan bahwa SLR terkait bagaimana seseorang mengatur proses pembelajarannya sendiri. Ada empat tahapan pengaturan diri (SLR), yaitu merencanakan, memonitor, mengontrol, dan refleksi. Pada pelaksanaan pembelajaran dengan pendekatan sainstifik dan pembelajaran berbasis masalah peserta didik lebih banyak melakukan kegiatan untuk menuntaskan setiap tahapan pembelajaran, guru belum memfasilitasi peserta didik untuk melakukan kegiatan SLR.

Berdasarkan analisis jawaban peserta didik, pengetahuan metakognitif gagal dalam pengetahuan deklaratif, prosedural, dan kondisional. Pada aspek pengetahuan deklaratif, peserta didik umumnya gagal dalam menemukan pengetahuan kunci dan menemukan pengetahuan spesifik untuk menjawab persoalan yang ditanyakan. Pada aspek pengetahuan prosedural, peserta didik gagal menyampaikan tahapan yang terstruktur dan terinci yang harus dilakukan untuk mendapatkan sebuah jawaban dari suatu pertanyaan. Pada aspek pengetahuan kondisional, peserta didik gagal menemukan kausal komparatif terhadap langkah yang digunakan dalam memecahkan sebuah persoalan, dan mengenali reservasi dari suatu kondisi.

Berdasarkan kelemahan yang dipaparkan, tampak bahwa peserta didik perlu mengenali pengetahuan kunci dan spesifik, pembelajaran dengan menggunakan peta konsep menjadi solusi masalah ini. Vanides, et al. (2005) menyatakan bahwa peta konsep mempunyai beberapa keuntungan bagi peserta didik, yaitu peserta didik memikirkan hubungan antaristilah sains yang telah dipelajarinya, mengorganisasi pemi- 
kiran dan memvisualisasikan hubungan konsep kunci secara sistematik, dan merefleksikan pemahaman mereka terhadap konsep. Adodo (2013) menyebutkan bahwa peta pikiran dapat digunakan untuk brainstorming, meringkas informasi dan mencatat hal penting, mengkonsolidasi informasi dari berbagai sumber berbeda, dan berpikir melalui masalah yang kompleks. Hasil penelitiannya menunjukkan peta pikiran sebagai strategi pembelajaran pengaturan diri (Self Regulated Learning/SRL) telah meningkatkan kinerja peserta didik dalam mata pelajaran sains dan teknologi dasar.

\section{PENUTUP}

\section{Simpulan}

Peserta didik secara potensial memiliki kesiapan untuk membangun pengetahuan metakognitif. Secara aktual peserta didik belum mampu mencapai pengetahuan metakognitif. Standar proses, terutama pendekatan saintifik dan pembelajaran berbasis masalah belum dapat meningkatkan pengetahuan metakognitif secara memadai. Apabila standar kelulusan pada kurikulum 2013 menuntut ketercapaian metakognitif, maka pendekatan pembelajaran haruslah diintegrasikan dengan metode-metode yang mampu melatih pengaturan diri peserta didik (Self Regulated Learner/SLR).

\section{Saran}

Pembelajaran dan tuntunan yang diberikan guru diharapkan dapat menarik zona aktual peserta didik (pengetahuan metakognitif rendah) ke zona ideal (pengetahuan metakognitif tinggi). Kurikulum 2013 menyediakan alternatif dalam pembelajaran, yaitu pendekatan ilmiah (scientific), tematik terpadu (tematik antarmata pelajaran), dan tematik (dalam suatu mata pelajaran), pembelajaran berbasis penyingkapan/ penelitian(discovery/inquirylearning), dan pendekatan pembelajaran yang menghasilkan karya berbasis pemecahan masalah (project based learning). Melalui penelitian eksperimental diharapkan dapat ditemukan hasil pengaruh dari pendekatan pembelajaran yang ditawarkan $\mathrm{Ku}-$ rikulum 2013 terhadap peningkatan pengetahuan metakognitif. Ragam scaffolding berbasis
Self Regulated Learner (SLR) seperti peta konsep, peta pikiran, dan peta argumentasi dapat diintegrasikan pada standar proses Kurikulum 2013 sebagai alternatif meningkatkan metakognitif.

\section{UCAPAN TERIMA KASIH}

Terima kasih diucapkan kepada Pusat Penelitian dan Pengembangan UIN Syarif Hidayatullah Jakarta yang telah mendanai penelitian ini melalui DIPA/BLU, Dr. Fonny D. Hutagalung yang telah memvalidasi isi instrumen; dan Renny Pujiati, S.Pd yang telah berkolaborasi dalam riset ini.

\section{DAFTAR PUSTAKA}

Adodo, S.O. 2013. "Effect of Mind-Mapping as a Self-Regulated Learning Strategy on Students' Achievement in Basic Science and Technology". Mediterranean Journal of Social Sciences, 4(6), hlm.163173.

Badan Pengembangan Sumber Daya Manusia Pendidikan dan Kebudayaan dan Penjaminan Mutu Pendidikan Kementerian Pendidikan dan Kebudayaan. 2013. Rasional Kurikulum 2013.

Balcikanli, C. 2011. "Metacognitive Awareness Inventory for Teachers (MAIT)". Electronic Journal of Research in Educational Psychology, 9(3), hlm.1309-1332.

Creswell, J.W. 2010. Research Design: Pendekatan Kualitatitf, Kuantitatif, dan Mixed (Terjemahan). Jakarta: Pustaka Pelajar.

Desmita. 2010. Psikologi Perkembangan Peserta Didik. Bandung: Remaja Rosdakarya.

Gassner, L., \& Warfvinge, G. 2009. “Developing Metacognitive Awareness a Modified Model of a PBL-tutorial Malmo University". Tesis Bachelor. 
Hake, R.R. 1999. Analizying Change/Gain Scores. Tersedia online di http://physics.indiana.edu.

Kemdikbud. 2013. Pengembangan Kurikulum 2013. Bahan PPT.

Kemendikbud. 2013. Peraturan Menteri Pendidikan dan Kebudayaan No. 54 Tahun 2013 tentang Standar Kelulusan. Jakarta: Kemendikbud.

Kemendikbud. 2013. Peraturan Menteri Pendidikan dan Kebudayaan No. 65 Tahun 2013 tentang Standar Proses. Jakarta: Kemendikbud.

Moll, L.C. 1990. Vygotsky's Zona Proximal Development. Infacia y Aprendizaje, 50 (51), hlm.157-168.

Ohio Literacy Resource Center. A Publication of the Ohio Literacy Resource Center (OLRC). Ohio: Kent State University. olrc@literacy.kent.edu.

Purnamawati. 2013. "Pengembangan Model Pembelajaran Bidang Keahlian Elektronika Industri Berbasis Metakognisi". Cakrawala Pendidikan, 32 (1): 41-53.

Rompayom, P., Tambunchong, C. Wongyounoi, S., \& Dechsri, P. 2010. "The Development of Metacognitive Inventory to Measure Students' Metacognitive Knowledge Related to Chemical Bonding Conceptions". Paper Presented at International Association for Educational Assessment (IAEA).

Schraw, G. \& Dennison, R.S. 1994. "Assessing Metacognitive Awareness". Contemporary Educational Psychology, 19. hlm460475.
Sperber, A. 2011. Cross-Cultural Research Translation and Linguistic Validation of Research Instruments into Other Languages. Tersedia online dihttp://romecriteria.org. Diunduh 12 April 2011.

Sperling, R.A., Howard, B.C., Miller, L.A., \& Murphy, C. 2002. "Measures of Children's Knowledge and Regulation of Cognition". Contemporary Educational Psychology, 27, hlm.51-79.

Vanides, J., Yin, Y., Tomita,M., \& Ruiz-Primo, M.A. 2005. "Using Concept map in the Science Classroom". Science Scope, 28 (8), hlm.27-31.

Whitebread, D. \& Cardenas, V.G. 2012. "Selfregulated Learning and Conceptual Development in Young Children: the Development of Biological Understanding". dalam Johar, A. \& Dori, Y.J. (eds), (Metacognition in Science Education: Trend in Current Research). New York: Springer. hlm.101-132.

Yildirim, S \& Ersözlü, Z.N. 2013. "The Relationship between Student's Metacognitive Awarness and Their Solutions to Similar Types of Mathematical Problems". Eurasia Journal of Mathematics, Science \& Technology Education, 9(4), hlm.411415.

Young, A. \& Fry, D. 2008. "Metacognitive Awareness and Academic Achievement in College Students". Journal of the Scholarship of Teaching and Learning, 8 (2), hlm. 1-10. 